\title{
ALLOCATION OF REORGANIZATION EXPENSES
}

\author{
SEYMOUR J. RUBIN $†$
}

"Ah, take the Cash and let the Credit go, Nor heed the rumble of a distant drum."

THE progress of a reorganization under Chapter X of the Bankruptcy Act carries with it some attendant expenses. Trustees and their counsel, creditors and their counsel, accountants, and the like, as well as referees, all are often necessarily employed during the course of the reorganization. Whether the reorganization fails, and the petition is dismissed, or straight bankruptcy is resorted to, or the reorganization is successful in the sense that a plan is approved and adopted, fees and expenses accrue. The problem may then arise whether or not secured creditors may be compelled to pay a share of these expenses.

\section{LIQUIDATION OR DisMissal}

For any one of several reasons, a petition for reorganization which has been approved by the court may be dismissed. In the decree of dismissal the court may or may not order liquidation under the orthodox provisions of the Bankruptcy Act. If dismissal alone is ordered, the fee question will generally be immediately raised. If liquidation is ordered, decision may be postponed. In either situation, it is important to decide (1) the amount of fees to which participants in the abortive reorganization are entitled, and (2) which claimants - secured creditors, unsecured creditors, or stockholders - are to bear the cost of the attempt at reorganization.

Whether fees may be charged to pledged assets may determine whether participants in an abortive reorganization do or do not receive compensation. In the Centralia Refining Company case, ${ }^{1}$ for example, the debtor filed a voluntary petition under Chapter X. The court approved the petition, appointed a temporary trustee (later made permanent), and authorized him to engage an auditor and counsel as aides. Under a later court order the trustee employed watchmen for the property and made the necessary expenditures for maintenance, including insurance. No question was raised as to the necessity for all these expenditures or the value of the services rendered.

† Attorney, Office of Price Administration; formerly Attorney, Reorganization Division, Securities and Exchange Commission.

Nothing herein should be construed as expressing the opinion of the Securitics and Exchange Commission or any member of its staff.

1. 35 F. Supp. 599 (E. D. Ill. 1940), (1941) 54 HARv. L. Rev. 1228. Cf. It ro Gage County Electric Co., C. C. H. 1940 Bankr. Serv. $\llbracket 52,602$ (D. Neb. 1940). 
It shortly became apparent, however, that no plan of reorganization was feasible. The court adjudged the debtor a banlirupt and directed liquidation under Section 238 of the Bankruptcy Act. ${ }^{2}$ At a later date in the bankruptcy proceedings, the trustee applied for a court order authorizing sale of certain of the debtor's liened property free and clear of the liens. Since other assets were not sufficient, the trustee sought to charge the liened property with all costs of administration for the entire period since the filing of the Chapter $\mathrm{X}$ petition. The court referred the matter to a referee, who found that the property of the bankrupt was worth $\$ 12,000$, that the liens covering the same property amounted to $\$ 18,000$, and, as a conclusion of law, that the property was chargeable with the necessary costs of preserving it -insurance, watchmen, light and power - but not with the general costs of administration - court costs, trustee's and counsel's fees, and expenses. The court affirmed the referee's decision, holding that lien creditors in an unsuccessful reorganization could be charged only with the necessary costs of preserving the property ${ }^{3}$ plus those costs which they had caused, which were incurred for their benefit, or to which they had consented.

Contrary to the Centralia case, the District Court for the District of Nebraska in the Gage Electric Company case ${ }^{\tilde{J}}$ asserted power to charge pledged assets with all the costs of an abortive reorganization, including fees awarded to court-appointed officials. Reading together Sections 241 to 246 , the court came to the conclusion that compensation might be allowed from pledged assets: ". . . Chapter 10 of the Bankruptcy Act provides for allowances by the court for certain services, including those of a trustee in a proceeding of this nature, and does not provide that the payment of such claims shall be made from property other than mortgaged property. Such allowances are to be paid on the same basis as the costs and fees of the officers of the bankruptcy court are paid."

2. 52 Stat. 899 (1938), 11 U. S. C. $\$ 638$ (1) (Supp. 1939).

3. Costs of preservation are always given priority over claims of sceurcd as well as unsecured creditors for obvious reasons. Louisville, Evansville \& St. Louis Ry. v. Wilson, 138 U. S. 501 (1891) ; Robinson v. Dickey, 36 F. (2d) 147 (C. C. A. 3d, 1929); cf. Randolph v. Scruggs, 190 U. S. 533 (1903); MacGregor v. Johnson-Cowdin-Emmerich, 31 F. (2d) 270 (C. C. A. 2d, 1929).

4. Just how it is to be determined that a numerous groun of bondholders have "consented to" the proceedings is a difficult question. The actions of a committce un their behalf might be opposed by a minority, and other complexities might result. (f. Is re Louisville Storage Co., 21 F. Supp. 897 (W. D. Ky. 1936). It scems sometimes to be implied that benefit and consent must both be present in order that the lienholder may be charged. See Robinson v. Dickey, 36 F. (2d) 147, 149 (C. C. A. 3d, 1930); Tawny v. Clemson, 81 F. (2d) 300, 304 (C. C. A. 4th, 1936). Cf. Seaboard Nat. Bank v. Rogers Milk Products Co., 21 F. (2d) 414,417 (C. C. A. 2d, 1927).

5. C. C. H. 1940 Bankr. Serv. $\llbracket 52,602$ (D. Neb. 1940).

6. The Centralia case does not cite the Gage Comnty case.

7. In re Gage County, C. C. H. Bankr. Serv 1940 \$ 52,612 (D. Xeb. 1944). An important limitation on fees allowable under the Gage Cumly case is the reading of 
Costs and fees in straight bankruptcy, however, are paid from free assets and not from mortgaged or pledged assets. Liens have priority over all expenses of administration other than costs of preservation of the property (or costs which are caused or consented to by the lienholders). ${ }^{8}$ The Centralia case transposes the orthodox bankrtuptcy rule into reorganization; the Gage County case, on the other hand, considers all assets in a Chapter $X$ proceeding (which affects the rights of all creditors, secured and unsecured) to be analogous to free assets in straight bankruptcy (which affects only the rights of unsecured creditors). The thesis of this article, that the Gage County view is preforable, can perhaps be best explained by tracing what seem to be the antecedents of the Centralia decision.

The question of applying straight bankruptcy fee standards to reorganizations first arose in cases under Section 77B involving the issue of amount of compensation - not priority of that amount. These cases generally held that the straight bankruptcy rule as to amount of compensation allowable applied if liquidation followed proceedings under Section 77B. ${ }^{9}$ The reasoning of a typical case was this: $:^{10}$ Section $77 \mathrm{~B}$ (c) (8) provided that the judge might direct liquidation if a plan of reorganization were not proposed or accepted. Section $77 B(k)(5)$ stated that if liquidation were directed "debts shall be entitled to priority as provided in Section 64." The court held that Section 77B(k)(5) was mandatory and that compensation was to be allowed as if all of the proceedings had been in straight bankruptcy, rather than on the more generous scale permitted by Section $77 \mathrm{~B}(\mathrm{c})(9) .{ }^{11}$

These cases did not, however, settle whether the amount allowed in an unsuccessful Section 77B proceeding could be paid out of mortgaged

Sections 241 to 246 to apply in the dismissal situation as well as where the reorganization is successful. Since no plan is ordinarily approved where dismissal is ordered, attorneys for creditors must prove that their services were in connection with the administration of the estate-a rather narrow concept-in order to prove their right to fees.

8. Louisville, Evansville \& St. Louis Ry. v. Wilson, 138 U. S. 501 (1891) ; In re Ivel Displays, 74 F. (2d) 702 (C. C. A. 2d, 1935); Title and Trust Co. v. Wernich, $68 \mathrm{~F}$. (2d) 811 (C. C. A. 9th, 1934).

9. Callaghan v. RFC, 297 U. S. 464 (1936); Sartorius v. Bardo, 95 F. (2d) 387 (C. C. A. 2d, 1938) ; In re Higgin Mfg. Co., 19 F. Supp. 120 (E. D. Ky. 1937) ; In rc Manhattan Music Hall, 14 F. Supp. 48 (S. D. N. Y. 1936); see In re Old Algiers, Inc, 100 F. (2d) 374 (C. C. A. 2d, 1938); In re Louisville Storage Co., 21 F. Supp. 897 (W. D. Ky. 1936). But $c f$. Oakland Hotel Co. v. Crocker First Nat. Bank, 85 F. (2d) 959 (C. C. A. 9th, 1936); cf. Comment (1937) 47 YALE L. J. 262, 271.

10. In re Manhattan Music Hall, 14 F. Supp. 48 (S. D. N. Y. 1936).

11. Section $77 B(c)(9)$ permits the court to "allow a reasonable compensation for the services rendered and reimbursement for the actual and necessary expenses incurred in connection with the plan by officers, parties in interest, depositaries, reorganization managers, and committees or other representatives of creditors or stocliholders, and the attorneys or agents of any of the foregoing." 
as well as free assets. In the Louisoille Storage Company case ${ }^{12}$ the court stated, as dictum, ${ }^{13}$ that the straight bankruptcy rule of priority applied, so that fee claimants might be paid only if free assets were available. But the secured creditor had requested the appointment of receivers; the court therefore held it had "caused" the receiver's and related fees, so that these fees might be paid from mortgaged assets.

Miners Savings Bank of Pittston \%. Joyce ${ }^{14}$ was a direct holding to the same effect as the Louisvillc dictum. The court ruled that reorganization benefited equity interests (and perhars unsecured crenlitnri) but not secured creditors:

"Where, as here, the business of the debtor was carried on prinr to the sale in the hope of reorganization the lienholder's forliearance in not foreclosing its lien, which enahled the business to lie thus carried on in the mortgaged property, was obviously for the henefit of the debtor and its general creditors. The fact that the mortgagee did not press for foreclosure but consented to permit the business to be carried on in the mortgaged property should not be held to penalize it by postponing its lien to the expenses of operating the business, since to so hold would be to place a penalty upon a lien creditor for its forbearance and for the consideration which it has shown for general creditors. ${ }^{10}$ This of course is not to say that the lienholder should not bear the reasonable expenses of preserving the property, which expenses were clearly for its benefit."16

The reasoning of the Minters and Louisille cases may be questioned. Inasmuch as an involuntary petition often embarrasses stockholders more than it does secured creditors, the general theory of the benevolence of secured creditors expressed in the Miners case may be inaccurate. However that may be, the terms of Chapter $\mathrm{X}$ afford ample reason for abandoning the result of the cases decided under Section 77B.

It is clear that the Section 77B rule as to amount of fees in a dismissed reorganization has been changed by Section 246.17 The Centralia case,

12. 21 F. Supp. S97 (W. D. Ky. 1936).

13. In the traditional, non-Llewellynian sense.

14. 97 F. (2d) 973 (C. C. A. 3d, 193S).

15. Compare the statement of Judge Learned Hand, in Sartorius v. Fardo, $95 \mathrm{E}$. (2d) 387,389 (C. C. A. 2d, 1938), that the conclusion that compensation cusuld nut ti: granted "follows from the nature of the proceeding and from the theory uf it which coerces recalcitrant creditors only upon conditions which by hylothesis are nut fulfilled."

16. 97 F. (2d) 973,977 (C. C. A. 3d, 1938).

17. In re Old Algiers, 100 F. (2d) 374 (C. C. 1. 2d, 1938). Scetion 246 directs that upon dismissal or entry of an order adjudicating the debtor a bankrunt "the judge may allow reasonable compensation for services rendered ... in such proseding prior to such dismissal or order of adjudication . . . and shall make frovision for the payment thereof ..." 
however, holds that even though amount is determined under the provisions of Chapter $\mathrm{X}$, ability to charge liened assets for those fees is still to be decided by reference to the provisions of straight bankruptcy. For several reasons, this conclusion seems dubious. Section 246 not only establishes a new scale of wages for counsel in an unsuccessful reorganization, but states that the court "shall make provision for the payment thereof. . . ."18 Where a debtor owns only mortgaged assets, any provision for payment of the fees made by the court would collide with the rule that lien creditors may not be charged for such administration expenses. ${ }^{10}$ In addition to this mandatory direction that the court make provision for payment, there is evidence contradicting the Centralia holding in the legislative history of Section 246. An extract from the report of the National Bankruptcy Conference to the House Committee on the Judiciary, dealing with an amendment to Section $77 \mathrm{~B}(\mathrm{c})(9)$, the substance of which was adopted as Section 246, is informative:

"We have built up the provisions to make it clear that allowances may be made for services rendered or disbursements incurred in a proceeding under this subsection, even though the plan may not be confirmed, but a liquidation directed or the proceeding dismissed. Such compensation and reimbursement should not of course be made to depend upon the contingency of a confirmation. If it is to be expected that responsible parties are to render effective service in a reorganization proceeding, provision must be made for reasonable compensation to them, regardless of the outcome of the proceedings. To do otherwise may invite into the proceedings less efficient and responsible persons." 20

18. Italics supplied.

19. It has been suggested that the result of the Centralia case might be rested on the ground that the order awarding priority over secured creditors must be made at the time when reorganization was terminated, and that no juriscliction to make such an order existed thereafter. (1941) 54 Hanv. L. Rev. 1228, 1229. Cf. In re James Butler Grocery Co., 100 F. (2d) 376 (C. C. A. 2d, 1938); but cf. In re White, 58 F. (2d) 203 (C. C. A. 2d, 1932). Such a rule is somewhat technical; and it has been held that the bankruptcy court which succeeds the reorganization court may thereafter grant parity of treatment to expenses of the reorganization and of the bankruptcy. In re Columbia Ribbon Co., 117 F. (2d) 999 (C. C. A. 3d, 1941). Cf. Missouri v. Earhart, 111 F. (2d) 992 (C. C. A. 8th, 1940). Furthermore, the Centralia case clearly assumes the power of the bankruptcy court to allow fees on the standard of Section 246, but merely denies power to charge secured creditors for those fees. The court may dismiss the proccedings and thus release the property. The power to provide for payment of the reorganization expenses at dismissal is the same as the power to provide for those expenses at entry of an order adjudging the debtor a bankrupt. Cf. In $r c$ Frank Realty Co., $31 \mathrm{~F}$. Supp. 816 (M. D. Pa. 1940). Cf. Miners Savings Bank of Pittston v. Joyce, 97 F. (2d) 973 (C. C. A. 3d, 1938). If the Centralia case can be whittled down to a narrow "holding" on a technical procedural point, the decision loses much of its importance and its interest. The problem of proper construction of Section 246, however, would still remtin.

20. ANalysis by National Bankruptcy Conference of H. R. 12889, 74th Cong", $2 d$ Sess. (1936), c. $3, \S 12$ (II) (d) (7). 
The Bankruptcy Conference report leaves little doubt that Section 246 was passed to correct the rule of the MIanhattan MIusic Holl case. ${ }^{.1}$ But it may be argued that the Conference did not intend to change the rule that expenses were not to be charged to secured creditors. Such an argument has several parts. The terms of Section $238^{\circ 2}$ may be relied on, since they provide that the proceedings are to be patterned, as near as may be, after straight bankruptcy; economy is aided by the rule of the Centralia case; and precedent may to some extent be relied upnn. But a reading of Sections 238 and 246 together certainly makes the meaning of Section 238 somewhat ambiguous $;{ }^{23}$ and the scales of statttory construction, on language alone, would seem in favor of the more generous rule. Economy is curiously achieved if obtained by denying all compensation to officers appointed by the court, who under the Ceatralia rule are forced to gamble on such unpredictable events as creditor acceptance of a plan. ${ }^{24}$ It is to be noted that a rule which denied adequate compensation to committees and their counsel was thought to be rectified by Section 246. It would seem to follow a fortiori that denial of compensation to trustees and other court-appointed officials shoull not occur. ${ }^{25}$

Furthermore, the argument that undue hardship results to fee applicants who are forced to gamble all compensation on the outcome of the proceeding is not entirely answered by the statement of Judge Caffey in the Manhattan Music Hall case that "it is common practice in general litigation, as well as in bankruptcy litigation, for creditors . . . to do much, and much which enhances the estate involved, and yet bear their

21. 14 F. Supp. 48 (S. D. N. Y. 1936).

22. Upon entry of an order directing that bankruptcy he prreseded with, "the proceeding shall thereafter be conducted so far as possible, in the same manner and with like effect as if an involuntary petition for adjudication had been filed at the time when the petition under this chapter was filed ...."

23. Nor is the matter clarified by the Senate Judiciary Committce renort, which states that the section "provides that where a reorganization prusceding suluredic a bankruptcy proceeding, and the former is then dismissed and bankruptcy proceeded with, allowances in the bankruptcy proceeding are to be governed by the rules applieable to such type of proceeding." Ses. Doc. No. 1916, 75th Cong., 3d Sess. (103\$) 33.

24. Compare, however, In re Lambertville Rubber Co., 111 F. (2d) 45 (C. C. A. 3i, 1940), in which the court apparently made the propriety of a payment of a tas and the consequent liability to surcharge of the trustee depend upon whether reorganization was or was not effected. That this puts a burden of prescience upon the trustee was somewhat feebly contested. It may be, however, that the court meant to declare that the possibility of successful reorganization was so remote that the particular payment was unreasonably made.

25. It may be possible, where there are some free assets available for fees but nut enough for trustees and other officials and committees, indenture trustees, etc., to remit the latter group to their clients, leaving the entire fund for the appointed officials. Cf. In re Columbia Ribbon Co., 117 F. (2d) 999 (C. C. A. 3d, 1941). 
own expenses." ${ }^{26}$ The analogy to contingent fees is strained when the fee-applicants are court-appointed trustees, receivers or the like, or when one of the applicants denied fees because of the immunity of mortgaged assets is an auditor or member of another profession where fees are not so commonly risked upon a decision as they are among the brethren of the coif.

Precedent is hardly conclusive. In the Old Algiers case, the court held that amount of compensation is to be determined under Section 246 despite entry of an order under Section 238.27 The National Bankruptcy Conference explanation of Section 246 seems to make inconsistent a construction of the statute which is generous as to computation of amount but leads to complete denial of that amount. The assumption of the Bankruptcy Conference report, that it is necessary to guarantee payment without regard to the fortuitous circumstance of confirmation in order to secure responsible and efficient service, may perhaps be more doubtft1 than the Conference thought. But given that assumption as the basis for Section 246, it would seem difficult to justify the construttion adopted in the Centralia case.

Implicit in the Centralia decision is the conclusion that fees may he paid from free assets. This is to place the entire burden of the provision in Section 246 upon unsecured creditors. The competence of the trustee and his counsel redounds to the possible benefit of all classes of creditors. ${ }^{28}$ The failure of reorganization may mean that the efforts on behalf of these classes have failed. But no reason appears why only unsecured creditors - who may not have instituted the proceedings, who may have demanded immediate liquidation, who may all along have protested the proceedings - should be made to pay the costs.

\section{Consummation of a Plan of Reorganization}

The problem of allocating fees and reorganization expenses is perhaps more important and certainly less observed where a plan is finally adopted and the proceedings are "successful" than in an abortive proceeding. In the usual case, a plan is worked out and accepted, a new corporation is

26. 14 F. Supp. 48,55 (S. D. N. Y. 1936).

27. In re Old Aigiers, 100 F. (2d) 374 (C. C. A. 2d, 1938).

It should be borne in mind that the requirement of good faith cuts across this entire field, so that proceedings uselessly prolonged may end with a denial of compensation. Thus, it may be relevant that a voluntary petition is filed at a time when foreclosure proceedings are pending, and when reorganization is obviously impracticable. If the obvious purpose of the petition is to obstruct the secured creditors in the realization on their security, it would be unjust to compel them to finance the obstruction. But this principle will bar compensation in few cases; and it would seem to have been inapplicable to the Centralia case.

28. Compare Tawney v. Clemson, 81 F. (2d) 300 (C. C. A. 4th, 1936). 
set up and the debtor's assets are transferred to it - all before fees are requested. This method of deferring consideration of the fee problem has certain implications which may best be explored by means of a hypothetical illustration.

The Jones-Smith Manufacturing Company owns a plant which is valued, for reorganization purposes, at $\$ 1,000,000$. It also has inventory and cash amounting to a total of $\$ 200,000$, which is not pledged under the lien of the mortgage. On the other side of the balance sheet are an outstanding bond issue of $\$ 1,500,000$, secured by the plant, and unsecured debts of $\$ 500,000$. The management has filed a voluntary petition. The company has previously been badly run, and a large burden has been thrown on the trustee, who, with his counsel, has worket strenuously to recover lost values, to prosecute neglected claims, and to draft a sound preliminary plan of reorganization. It may be estimated that the fees of the trustee and his counsel will come to $\$ 200,000$ fan amount which we make large for illustrative purposes). It is called to the attention of counsel for the trustee that a problem of fee allncation exists. What effect should this problem have on counsel's drafting of a plan?

First, a problem not related to apportionment arises: what amount of securities should be issued? If anticipated fees of $\$ 200,000$ are deducted before transfer of the assets to the new corporation, the new corporation should have a total capitalization of only $\$ 1,000,000.0^{23}$ The tendency, however, is probably to ignore the fees matter in deciding the amount of securities to be issued. In most cases, the fees will take a small enough part of the total assets so that the capitalization - which is necessarily not mathematically precise in any case - is not thrown far off.

Secondly, the problem of allocating fees and expenses allows the trustee's counsel to choose among several possible courses of action: he may allocate or not; and he may settle the problem prior to the issuance of the securities of the reorganized corporation, or later. Any combinations of these alternatives would seem to lead to a necessary determination of the allocation issue.

A determination, prior to issuance of securities, that there should be no allocation. If counsel comes to this conclusion, it seems clear that there exists no equity for the unsecured creditors. Free assets are to bear, so far as they are able, the costs of reorganization. The estimated costs exhaust the free assets. Therefore, no securities should be issued to the unsecured creditors.

A determination, prior to issuance of securities, that there should be an allocation. In this event, counsel will draft a plan which gives some

29. Case v. Los Angeles Lumber Products Co., 303 U. S. 106 (1939); cf. Dodd, The Los Angeles Lumber Products Conpany Case and Its Implicotions (1940) 53 Hanv. L. REv. 713. 
participation in the reorganized corporation to the unsecured creditors ${ }^{80}$ Since not all of the estimated expenses of $\$ 200,000$ are to be paid from the free assets, some participation must be given to the tunsecured claimants. The amount of this participation, however, depends largely upon the formula used in determining the allocation of the expenses. If expenses are allocated in the ratio which one set of assets bears to the other, secured creditors, having the largest amount of assets, will bear the bulk of the reorganization expenses, and unsecured creditors may expect a substantial participation in the new corporation. If, on the other hand, unsecured creditors are required to bear the bulk of expenses because they are the marginal group benefiting most from the reorganization, their participation in the new corporation would be cut down. A determination that the question of allocation need not be setlled until after securities are distributed under the plan. It is clear that, in this event, counsel has not succeeded in avoiding the problem. ${ }^{31}$ No doubt, it would seem at first glance that counsel has decided that there should be no allocation. This appears to be so, since distribution of securities is to be based upon proportions existing before allocation, ${ }^{\text {ga }}$ and there will be no opportunity to do otherwise than have fees paid by the corporation after securities are distributed. But this apparent decision may often be illusory. Whether allocation does or does not take place will depend upon the plan proposed. To illustrate: if the secured creditors are given new bonds, and the unsecured creditors are given common stock, payments by the new corporation of the reorganization expenses from current assets, or cash, would in reality be payment by the unsecured creditors in their new capacity as common stockholders. On the other hand, if under the plan some common stock is issued to the old bondholders, to the extent that that common stock is diminished in value or in expectation of dividends by the payment of the rearganization expenses, the old bondholders bear a share of those expenses. Furthermore, if an all common stock plan is adopted, and if distribution of the stock is made on the basis of the assets available to the secured and the unsecured creditors prior to deduction of expenses, then the reorganiza-

30. Who, of course, would include the secured creditors to the extent of their deficiency.

31. Similarly, the problem is not avoided if the trustee does not have sufficient cash to operate the business and raises these funds by issuing certificates secured by the property. These certificates may rank ahead of the bonds. In re Prima Co., $88 \mathrm{~F}$. (2d) 785 (C. C. A. 7th, 1937), 85 U. of PA. L. Rev. 736; see Comment (1937) 47 YALE L. J. 262,271 . If funds raised by issuance of these certificates are used to pay rcorganization expenses, the source from which the certificates are paid at maturity will of course determine on what class of assets and what class of creditors the expenses have fallen.

32. Whether or not the total amount of securities to be issued is decreased by the estimated amount of expenses. 
tion expenses are actually divided between secured and unsecured creditors in the ratio that liened assets bear to free assets.

\section{The Destrability of Apportionatent}

It seems evident that the problem of apportionment is inescapable and that the answer is not so clear. Fees in a successful reorganization may be charged to pledged assets, as in the fairly common case in which all of the property is under mortgage and no equity exists for anyone other than the secured creditors. ${ }^{33}$ Whether, in the situation in which there are both free and liened assets, fees should he apportioned, is a different matter.

It may be argued that free assets should bear, so far as is possible, the reorganization expenses for a number of reasons. First, since this is the rule in straight bankruptcy, why not in reorganization? Secondly, a reorganization benefits the marginal, unsecured creditors far more than it does the secured creditors. And insofar as the reorganization, by postponing the right of the secured creditors to liquidate. creates an equity for the unsecured creditors, the latter should, it is argued, bear the costs of the proceeding. Finally, an apportionment rule would be complicated and difficult, especially since statement of a formula has never been made.

As to the first and second arguments, it should be observed, however, that since reorganization is a different process from bankruptcy liquidation, different rules are entirely reasonable. It has already been noted that Section 246 puts into the determination of fees in a reorganization superseded by bankruptcy a standard different from that of straight bankruptcy. Determination of amount is thus different in the two branches of the Bankruptcy Act; determination of the payor of expenses may also vary, though here the statutory direction is far from clear. ${ }^{34}$ In bankruptcy, the object of the proceedings is to liquidate and to distribute the assets equitably. The secured creditors have little to gain from the bankruptcy proceedings. They will be charged, it has been held, ${ }^{35}$ the amount which it would have cost them to foreclose their lien in another way. Beyond this, especially if their security is adequate, the proceedings have little or no relation to their benefit.

Reorganization, on the other hand, tends to benefit secured creditors as much as or more than unsecured creditors. The going concern value of

33. Compare In re Prima Co., \&S F. (2d) 785 (C. C. A. 7th, 1937), where the court allowed the issuance of receiver's certificates with priority over the secured claims in order to obtain funds for administration.

34. It will be recognized that this mere statement that "reorganization is different" is hardly an answer except to the first argument-that of the "why not" type. The solution is furthered neither by the question nor its answer.

35. Odendahl v. Pokorny Realty Co., 76 F. (2d) 271 (C. C. A. 5th, 1935). 
the property is preserved. And it is a fact that in any case in which the value of the security at its liquidation price is less than the amount of the secured claims, it is the secured rather than the tunsecured creditors who benefit from the preservation of going concern value. ${ }^{30}$ In the above hypothetical case, the value of the mortgaged property was $\$ 1,000,000$, and the amount of secured claims $\$ 1,500,000$. Unsecured creditors, in such a case, might benefit as much by immediate distribur tion of the free assets as by a lengthy reorganization. Their hope of gain lies in the possibility that the preservation of the going concern value of the property will reduce the deficiency claim of the secured creditors against free assets. But this hope of gain is reduced to a shadow if all of the reorganization expenses are charged to them. Immediate distribution, before the expenses of reorganization can be incurred, would seem their best choice. The reorganization, in such a case, is for the benefit of the secured creditors, or, to put it in terms of things, for the enhancement of the liened assets rather than of the free assets.

To pay reorganization expenses from free assets before liened assets are touched is to grant to the secured creditors a priority in assets to which they have a claim only to the extent of the deficiency, and a claim which is entitled only to parity with the unsecured creditors. Free assets would seem to bear the same relation to unsecured creditors as liened assets to secured creditors. In substance, the free assets are the security for the unsecured claims. Consequently, the unsecured creditors should not be compelled to give up their "security" so that the lienholders may more fully enjoy theirs.

A closely analogous problem was raised and settled in favor of allocation in Tawney v. Clemson. ${ }^{37}$. In that straight bankruptcy proceeding, the district court had not charged the entire expenses to the "general fund" available to unsecured creditors, but had partially allocated:

"The mortgagee also excepted to the account because the referee charged against the proceeds of the sale of the mortgaged property a share of the expenses of the sale and of the commissions of the referee and trustee in the proportion which the proceeds of the mortgaged property, bore to the proceeds of the property that was free from the liens. General expenses of administration, such as amounts due the referee for notices, filing of claims, and amounts due attorneys for services rendered to the estate, were not pro rated but were charged against the general fund. The mortgaged property sold for enough to pay the mortgage debts, but when the pro rata share of the expenses and commissions was deducted, there was a

36. As is indicated infra, p. 429 , the jmior secured creditors have received the benefit of this preservation of value, and so should bear the part of the expenses allocated to secured creditors.

37. 81 F. (2d) 300 (C. C. A. 4 th, 1936). 
balance remaining due on the mortgages which was allowed to participate in the general estate only as an unsecured debt." 39

The court held the allocation to be authorized, since the expenses allocated were partially for the benefit of the secured creditors:

" No equitable consideration . . . excuses a lienor, who seeks the aid of the bankruptcy court, from paying such part of the costs of the sale and of the expenses of administration as is attrilutable to the sale of the mortgaged property and the distribution of its proceeds." 39

The problem in a reorganization is similar. Tainney $v$. Cleanson holds that a secured creditor must pay for that portion of the services which are for his benefit; in a reorganization under Chapter $\mathrm{X}$, all services are partially for the benefit of the secured creditor, since the principal object of the proceedings is generally to preserve his security with a going concern value, rather than a forced sale value. A railroad reorganization, for example, would certainly benefit holders of a divisional mortgage as much as holders of the company's debentures.

Since it is the value of the liened property which is preserved in reorganization, it would seem fair that those having an interest in that property should pay a part of the cost of the proceedings. As between claimants to that property, however, the costs should be borne by the junior claimants. If preservation of going concern value makes possible inclusion of a second mortgagee who otherwise would be eliminated, that junior mortgagee rather than the senior mortgagee should bear the cost. In other words, the allocation is between liened and free assets, rather than between classes of creditors. The allocation doctrine thus is placed on a logical basis of payment by those who receive benefit for benefits received - entirely consistent with the straight bankruptcy practice.

That complexities occur is obvious. The yoing concern value of the property subject to mortgage may include some equity for the debtor, which would inure to the benefit of the debtor's general, unsecured creditors, who might, on the basis of the above analysis, have the entirety of the fees apportioned between their interest in the equity in the mortgaged property and their claim to the free assets. For example, where apportionment of part of the expenses is made to liened assets, junior interests having a claim to those assets would bear the burden of the ayportionment: thus, if unsecured creditors had an equity of $\$ 200,000$ in the mortgaged property, and there were free assets worth $\$ 200,000$, it would obviously be useless to apportion the reorganization expenses

38. 81 F. (2d) $300,303-04$ (C.C.A. 4th, 1936).

39. Id. at 304 . 
(of, say, $\$ 100,000$ ) between the equity and the free assets. The result to the unsecured creditors - or to the stockholders - would be the same in one case as in the other. The obverse of the coin would be the case where the deficiency claim of the secured creditors was large in proportion to the claim of the persons with no security for their claims. In this latter case, it would make little difference whether the free assets bore all or an apportioned share of the expenses, for the secured creditors, in their capacity as deficiency claimants, would in any case get the lion's share of what was left of the free assets. This is merely to state what perhaps is obvious, that if the unsecured creditors have only a small share in the free assets, apportionment of expenses will not greatly increase that share.

Finally, it cannot be denied that a rule for allocating expenses between classes of claimants might be complicated and difficult. A tentative formula might be to apportion costs in the ratio that liened and free assets bear to the total assets; this would seem neither complicated nor difficult of application. ${ }^{40}$ If liened assets were $\$ 1,000,000$, and free assets were $\$ 200,000$, costs might be allocated on a 5-1 basis. Costs of $\$ 100,000$ would thus be distributed by charging $\$ 17,777.77+$ to the free assets, and $\$ 82,222.22+$ to the liened assets. Such a suggestion needs further study; but it would seem to bear some sort of reasonable relation to benefits received.

Whatever the rule by which costs are allocated, it would seem desirable to smoke the problem into the open, and to give some consideration to whether the present fortuitous method of distributing the cost of a reorganization should continue. It would be unfortunate if the present practice should go unremarked, or if what seems to be the undesirable result of the Centralia case should be adopted in a completed reorganization.

40. Such a formula was used in Tawney v. Clemson, 81 F. (2d) 300 (C. C. A. 4th, 1936). 